\title{
Early Regeneration
}

National Cancer Institute

\section{Source}

National Cancer Institute. Early Regeneration. NCI Thesaurus. Code C96178.

Early reconstitution of a lost or injured part. 